\title{
Normative Power in EU's Democracy Promotion Policy towards Sub-Saharan Africa: A Critical Assessment from Zimbabwean and Ivory Coast Cases
}

\author{
Samiratou DIPAMA* \\ Emel PARLAR DAL ${ }^{* *}$
}

\begin{abstract}
This paper seeks to explore the limits of the Normative Power Europe (NPE)'s concept from theoretical and empirical perspectives by using Zimbabwe and Ivory Coast as test case studies. In doing so, it will first theorize the concept of NPE by analyzing the liberal understandings and neorealist critiques of the concept, then it will briefly give an overview of the Cotonou Partnership Agreement (CPA) framework and finally it will critically examine the EU's democracy promotion activities in both countries from the NPE perspective. Our main argument is that though normative emphasis finds its place in the CPA Framework, the EU's inconsistent and controversial attitude towards the political situation in Zimbabwe and Ivory Coast, have significantly limited conceptions of the EU as a normative power because strategic interests calculations have constantly trumped EU's normative aspirations.
\end{abstract}

Keywords: Sub-Saharan Africa, European Union, Normative Power Europe, Political conditionality, Democracy Promotion

\section{Avrupa Birliği'nin Sahra-Altı Afrikası'na Yönelik Demokrasi Teşvik Politikalarında Normatif Güç̧: Zimbabve ve Fildişi Sahili Vakalarının Eleştirel Değerlendirmesi}

Öz

Bu makale, Zimbabve ve Fildişi Sahili vakalarını kullanarak Normatif Güç Avrupa kavramının kuramsal ve ampirik açıdan sınırlarını incelemeyi amaçlamaktadır. Bunu yaparken ilk olarak Normatif Güç Avrupa kavramını, bu kavrama yönelik liberal yaklaşımları ve neo-realist eleştirileri inceleyerek kuramsallaştıracak; daha sonrasında Cotonou Ortaklık Anlaşması çerçevesine kısaca göz atacak ve

* $\quad$ PhD Student, Marmara University, EU Politics and International Relations, European Union Institute, dipamamis@yahoo.fr, samiratoudipama@marun.edu.tr

** Associate Professor, Marmara University, Faculty of Political Science, Department of International Relations, emelparlar@yahoo.com, emel.parlar@marmara.edu.tr 
son olarak, Avrupa Birliğinnin iki ülkedeki demokrasiyi teşvik etmeye yönelik faaliyetlerini Normatif Güç Avrupa perspektifinden eleştirel olarak inceleyecektir. Makalenin temel savı, normatif vurgunun Cotonou Ortaklık Anlaşması Çerçevesi’nde yerini bulmasına rağmen, stratejik çıkar hesaplarının devamlı olarak Avrupa Birliği’nin normatif amaçlarına baskın çıkması nedeniyle, Avrupa Birliği’nin Zimbabve ve Fildişi Sahili’ndeki siyasi durumlara yönelik tutarsız ve tartışmalı tutumu Avrupa Birliği’nin normatif güç olarak kavramsallaştırılmasını büyük ölçüde sınırlandırmıştır.

Anahtar kelimeler: Sahra-Altı Afrika, Avrupa Birliği, Normatif Güç Avrupa, Siyasi Şartlllık, Demokrasiyi Teşvik

\section{Introduction}

Self-describing itself as a normative power, the European Union (EU) has bore the moral responsibility to spread its normative values to the rest of the world in order to achieve its normative ends of a peaceful global world. In this context, the former $4^{\text {th }}$ Lome -bis agreement and the recent Cotonou Partnership Agreement (CPA) concluded between the EU and the African, Caribbean and Pacific (ACP) group of states by including a conditionality clause, has initially provided the legal framework for the EU to make its economic and diplomatic relationship with the ACP countries dependent upon progress towards respect of democratic principles and human rights in these partner countries. The EU has then apparently been playing a highly 'normative' role using its economic and diplomatic instruments to foster the spread of norms on democracy and human rights in these regions. However, the EU's democracy promotion policy, especially towards Africa, has generally been subject of heated debates among scholars, policy-makers and academics and has raised questions about the Union's role as an external normative power. Critics generally perceive the EU's democracy promotion policy as being characterized by "double standards", meaning that similar violations of democratic principles have led to a different response from the EU (Del Biondo, 2011). This paper seeks to explore the limits of the Normative Power Europe's concept in Sub-Saharan Africa (SSA) from theoretical and empirical perspectives by using Zimbabwe and Ivory Coast as country-case studies. In doing so, it will first theorize the concept of NPE by analyzing its core tenets and critiques, then it will briefly give an overview of the CPA framework and finally it will critically examine the EU's democracy promotion activities in both countries from the NPE perspective for the period between 2000-2014.

\section{Theory of Normative Power Europe and Historical Evolution of EU's Policy of Political Conditionality towards SSA}

This section seeks to theoretically grasp the concept of NPE and its critiques and to briefly explore the successive frameworks that have regulated the EU's relations with Sub-Saharan African countries. 


\section{EU Normative Power in Theory: Main Tenets and Critiques}

The concept of 'normative power Europe' was first introduced by Manners in 2002 to suggest that the particularity of the EU stems from its ability to shape conceptions of 'normal' in international politics (Manners, 2002:240). The term 'power' in normative power concept is specifically defined "in Weberian terms as a form of relationship between the two actors where one of them impacts the other to adopt the norms/values which in different circumstances the latter would not accept" (Metreveli, 2011:2). This conceptualization of power brings it closer to Nye's concept of soft power introduced in 1990 and defined as "the ability to get what you want through attraction rather than through coercion"(Nye, 2005). Therefore, a normative power is expected to predominantly make use of soft power in the pursuit of its normative ends rather than hardcore measures, which are mainly about the use of military and economic force to influence others' decisions and actions (Hill and Smith, 2011: 475).

This normative difference of the EU stems from its historical context, hybrid polity and politicallegal constitution (Manners, 2002: 240). The EU has been constructed on the basis of core norms and values, universally recognized and shared and these norms dictate and should dictate its foreign policy. Manners argues that EU's normative power has been built on the basis of five "core norms" (peace, democracy, liberty, rule of law, and human rights) and four 'minor norms' (social solidarity, fight against discriminations, sustainable development and good governance" (Manners, 2002:242-243). This conceptualization of the EU as a normative power is also observed in some European political leaders' discourses, which have become an increasingly important practice of European identity construction (Diez, 2005: 635). To illustrate this point, the then European Commission President, Romano Prodi, in a speech to the European Parliament, once stated that, "Europe needs to project its model of society into the wider world. We are not simply here to defend our own interests... We have forged a model of development and continental integration based on the principles of democracy, freedom and solidarity - and it is a model that works" (Prodi, 2000).

Yet, Manners also suggest that having a normative basis does not suffice to make a political institution an effective normative power. There should also be a diffusion of these norms to other entities in order to make it a normative power (Manners, 2002:244-245). In this vein, Manners underlines six different mechanisms of norm diffusion, which include contagion, informational diffusion, procedural diffusion, transference, overt diffusion and the cultural filter (Manners, 2002: 244-245). The inclusion of political conditionality clause in EU's cooperation framework with third countries constitutes one of the ways of promoting and diffusing EU norms and values. The NPE further suggests that "not only is the EU constructed on a normative basis, but importantly that this predisposes it to act in a normative way" (Manners, 2002:252) in world politics. This basically means that the EU is normally expected to value norms more than strategic interests in the shaping and conduct of its foreign policy towards third countries. By anticipation to the criticisms of the eventual inconsistencies in the conduct of EU foreign policy, Manners 
concludes that "the most important factor shaping the international role of the EU is not what it does or what it says, but what it is"(Manners, 2002: 252).

At the turn of the century, there has been growing neorealist criticisms against the idea of the EU as a distinctive normative power. Neorealist critique does not reject the NPE's assumption that states pursue a range of ethical concerns reflecting their distinct political values, such as the promotion of democracy and human rights. Yet, their main argument is that these ethical concerns are always of second order concern, which means that these are always traded off with vital national security fundamental national interests in case of conflict. In this stance, HydePrice recognizes that the rationale behind the states' engagement in normative issues is always being "aware of the structural distribution of power in the international system, and [they] do not pursue their normative agendas at the expense of their vital national interests" (Hyde-Price, 2008: 31). For instance, with respect to the EU's policy of democratization of central and eastern European countries in the post-cold war era, Hyde-Price argues that "the EU was used by its most influential member states as an instrument for collectively exercising hegemonic power, shaping its 'near abroad' in ways amenable to the long-term strategic and economic interests of its member states" (Hyde-Price,2006: 226-227). Therefore, great powers like the EU, are interested in sustaining a peaceful environment around them because it correlates with their own security and they have the capabilities to do so (Waltz, 1979:198). Thus, they would pursue "milieu goals" by using their material capabilities both as a means for influencing others and shaping a stable external environment (Hyde-Price, 2008: 31). Therefore, from a neorealist perspective, the "EU external policy co-operation constitutes a collective attempt at milieu shaping, driven primarily by the Union's largest powers "(Hyde-Price, 2006:222). In other words, "normativity is just an instrument in the EU's tool box in pursuing its aims” (Cebeci, 2012:576).

Moreover, the fact that strategic interests rather than norms are of outmost importance in shaping EU's foreign policy implies that "(...) if there is a conflict between democracy promotion and security, the EU will always give higher priority to security. Only in those cases where other, more important issues are not at stake will the EU seek to promote democracy with considerable consistency and vigor" (Olsen, 2002: 133). Thus, "EU member states will only allow the EU to act as the repository for shared ethical concerns as long as this does not conflict with their core national interests"(Hyde-Price, 2006:223). This primacy of national interests over normative issues explains why the EU and its member states would engage in economic relations with Putin's Russia would sale arms to authoritarian China (Hyde-Price, 2006:223) or would cooperate with authoritarian regimes in Africa and the Middle East.

Other critics pertains to the lack of sanctions in the EU itself against member states that would eventually contravene to the EU's settled norms and values as another signal that EU cannot be an effective normative power (Sjursen, 2006: 246). Cases of Britain's military intervention in Iraq in 2003 despite opposition from France and Germany (Blair, 2004: 207), as well as France and Britain's military intervention in Libya in 2011 despite opposition from many EU member states, clearly illustrates EU's member states' incapacity “to form a coherent normative policy towards an 
issue" (Hardwick, 2011) due to the prevalence of national interests considerations and highlights the inner limits of EU's normative power identity.

\section{Political Conditionality in EU-SSA Relations: from Lome to Cotonou}

Before the $4^{\text {th }}$ Lomé Convention, the agreements were kept neutral with regard to human rights and democracy. The development and events of the 1980s, with the ACP states facing a severe debt crisis and being therefore in a weak bargaining position, has led to the gradual inclusion of political conditionality whereby access to aid is being tied to the adherence of international human rights standards for the first time (Crawford, 1996:505). For the first time "a political element" making "respect for human rights" a fundamental clause of the agreement was introduced in Article 5 of $4^{\text {th }}$ Lome Convention There was however still no clause making human rights an essential element of the Convention, nor one providing for its suspension in the event of human rights violations.

The gradual evolution towards conditionality was deepen when the $4^{\text {th }}$ Lomé Convention, amended in 1995 following a mid-term review, adds to the human rights clause, respect for democratic principles, the rule of law and good governance as "essential elements" of the convention and includes a suspension clause (article 366a). This finally gave the commission the legal basis to totally or partially suspend the application of the Convention after prior consultation of other ACP nations and the abusing party (Ozveri, 2011:3). Yet, article 366a did not address which measures should be taken to resume cooperation. The framework established by the $4^{\text {th }}$ Lomé Convention provided therefore the European Community with complete discretion over when measures were lifted (Arts, 2000:193). The mid-term review further introduced a performance-based aid allocation. The $4^{\text {th }}$ Lomé convention was succeeded by the Cotonou Partnership Agreement (CPA) in 2000, which is valid until 2020. The CPA entered into force almost 3 years later in April 2003 and provides for a revision every five years. The new CPA reflected the transition from purely economic cooperation to more inclusive political agreements in development policy. It built upon three pillars; an economic trade and cooperation pillar, a development cooperation pillar, and a pillar dealing with the political dimension. The big area of change concerns the political dimension in that Art 9 not only reiterates the notion of human rights, democratic principles and rule of law introduced in $4^{\text {th }}$ Lomé-bis convention, but also makes reference to good governance, which is said to be a "fundamental element of this agreement". As under the revised $4^{\text {th }}$ Lomé Convention, in case of violation of the essential elements of human rights, democratic principles and rule of law a consultation procedure will be started to see what measures can be taken to remedy the situation (article 96). Article 96 also foresees deadlines. Consultations shall begin no later than 30 days after invitation and shall not last longer than 120 days. Once a serious breach of human rights or democratic principles is observed, the council of the EU invites the ACP country in question to participate in consultations under article 96. The decision to start consultations under the Cotonou Agreement is taken by the Foreign Affairs Council on the basis of a proposal 
tabled by a EU member state or by the European External Action Service (EEAS) in collaboration with the European commission.

Consultations start with a meeting in Brussels between the EU, the ACP country accompanied by number of ACP countries of its choice, and representatives from regional organizations such as the AU and ACP-secretariat. The EU and the responsible government adopt a list of commitments to be fulfilled within a timetable. When consultations are closed, the EU evaluates the progress made by the government in fulfilling the commitments undertaken to rectify the breach and may decide to take "appropriate measures". It is often argued that most common strategy followed by the EU in the context of consultations consists of:

1. the redirection of aid to measures designed to fulfill the authorities' commitments to redress breaches, most notably actions supporting the preparation of elections; and

2. the incremental resumption of development cooperation on a conditional basis.

Beyond the use of "appropriate measures" under the article 96 of the CPA, the Treaty on European Union (TEU) includes "restrictive measures" as one of the possible tools that can be employed under the Common Foreign and Security Policy (CFSP) to enhance the compliance of governments under sanctions of the article 96(European Commission, 2008). As for the CPA, restrictive measures imposed by the EU under CSFP may target governments of third countries, or non-state entities and individuals (such as terrorist groups and terrorists) (European Commission, 2008). The conditions and circumstances under which CSFP sanctions can be used are strictly regulated through elaborated principles by many European governments and EU institutions and these principles include the following: "Sanctions should target as closely as possible the individuals and entities responsible for the undesirable policies and actions, thus minimizing adverse effects on others (...) They must respect human rights and fundamentals freedoms, in particular due process and the right to an effective remedy. The measures imposed must always be proportionate to their objective" (European Commission, 2008). The EU can use the following sanctions against the ACP states under the CSFP framework: diplomatic sanctions; Boycotts of sport or cultural events; Trade sanctions (general or specific trade sanctions, arms embargoes); financial sanctions (freezing of funds of economic resources, prohibition on financial transactions, restrictions on export credits or investment); flight bans; and restrictions on admission. Regarding the implementation, arms embargoes or restrictions on admission are implemented directly by the Member States.

\section{EU Normative Power on the Ground: Zimbabwean and Ivorian Cases in Perspective}

This part will give a brief overview of the EU's democracy promotion activities in Zimbabwe and Ivory Coast and then critically examine the limits of the EU's normative power on the basis on the empirical analysis of the role it played in this context. 


\section{Brief Overview of the Case Studies In Zimbabwe}

Robert Mugabe and the Zimbabwe African National Union-Patriotic Front (ZANU-PF), first brought to power in relatively democratic elections, have since ruled the country. Zimbabwe's development achievements and racial reconciliation during the first decade of independence were internationally celebrated (Freedom House Zimbabwe, 2012).

The main western-oriented opposition party, Movement for Democratic Change (MDC) managed to gain 57 out of 120 seats in the 2000 parliamentary elections. Conscious of this growing position of the opposition party, Mugabe's government turned increasingly towards violence and intimidation of the opposition, civil society and journalists. MDC members were harassed, arrested and even killed (International Crisis Group , 2002).

A few days after the 2002 elections, more than 1,400 people were arrested nationwide; most of them poll agents or observers from civil society (Amnesty International, 2002). In 2004, a bill was adopted that banned international human rights groups and prevented civil society organizations that received foreign funding from working on human rights (Amnesty International, 2004).

The 2005 parliamentary elections were largely marked with intimidation, violence and the use of food as a political weapon as well as the abduction of opposition party members by the ZANU-PF resulting in an even greater extent the split between the ZANU-PF and the MDC.

The situation worsened during the March 2008 presidential elections held in "an atmosphere characterized by severe economic meltdown, hyperinflation and mass political violence, as well as by a massive emigration of Zimbabweans" (Grebe, 2010). Election results were very close between the ZANU-PF and MDC and led to runoff elections at the end of June. Before this could take place, the opposition leader Morgan Tsvangirai, closely supported by the EU and the international community withdrew his candidature in protest of the unfair elections and political violence (Grebe, 2010).

The following months were followed by a negotiation between Mugabe and Tsvangirai, which finally reached a power sharing agreement, and formed a unity government under the Global Political Agreement (GPA) in September 2008(Grebe ,2010).

In the run-up of the 2013 elections, report from the Reporter Without Borders "expresses its grave concern for freedom of information in Zimbabwe and the safety of local journalists after threats and attacks by members of the Movement for Democratic Change" (Reporter without Border,2013). Therefore, "The ruling ZANU-PF party is not alone in showing hostility to the media and in opposing press freedom and there is the risk that the EU is "supporting" a party which itself is not democratic, the MDC. Mugabe overwhelmingly won the July 31 vote but his main rival, Morgan Tsvangirai, denounced it as a "huge fraud". The African Union declared that the elections were "free, honest and credible" (BBC News, 2013). The South African Development 
Community (SADC) called the election "free and peaceful" but reserved judgment on its fairness (LegalBrief Today, 2013).

\section{In Ivory Coast}

On 24 December 1999, Ivory Coast entered a period of conflict after a coup by soldiers led by General Robert Guei, putting down the president Henri Konan Bedie. In a July 2000 referendum, the Ivorian people approved a new constitution and electoral code, by an 86 percent majority. The revised constitution tightened presidential eligibility requirements, including a stipulation that a candidate's parents both have to be Ivorian and that the candidate must never have held another nationality. The Supreme Court ruled in October 2000 that Alassane Dramane Ouattara, the leader of the mainly Muslim party Rally of Republicans (RDR), did not meet the nationality rules and could not run for the elections.

The October 2000 elections were supposed to bring a relatively smooth restoration of democracy, but things went terribly wrong. The openness of the elections was questioned and the results that proclaimed Laurent Gbagbo winner were contested by the party of Alassane Ouattara (who were not allowed to participate) and the party of the putchiste Robert Guei. Laurent Gbagbo called his supporters to descend on the streets and to require the respect of the results by the other candidate. Finally, Laurent Gbagbo gained power through street. Similarly, the legislative elections on 10 December 2000 excluded Alassane Ouattara from the competition on citizenship grounds and to replicate all the RDR boycotted the elections by removing all its candidates. The protest organized by the RDR in Abidjan escalated into violent clashes with the loyal forces to president Gbagbo (Bouquet, 2011:67). In August 2002, Gbagbo formed a government of national unity with members of the RDR (US State Department, 2011).

These positive steps were halted in September 2002, when the Mouvement Patriotique de Côte d'Ivoire (MPCI), rebellious military personnel exiled in Burkina Faso, attacked government ministries in Abidjan, Bouake and Korhogo. After it was suppressed in Abidjan, the rebellion withdrew to the north and the center of the country. In the west, two other rebel movements, the Mouvement Populaire Ivorien du Grand Ouest (MPIGO) and the Mouvement pour la Justice et la Paix (MPJ) fought for western cities. The war led to a complete division of the country, with the MPCI in the north, MPIGO and MPJ in the west and the government in the south (Blé Kessé, 2005: 116-118). In December 2002, the three rebel groups formed the Forces Nouvelles.

The January 2003 Linas-Marcoussis Agreement included the revision of the conditions for the eligibility of the presidency and aimed to improve conditions for Ivoirians with foreign origin. A prime minister with executive powers would be appointed, and a government of national unity would rule until general elections in 2005 (International Crisis Group, 2003:31-32). The partiality of the France's role was put in doubt by the partisans of the Laurent GBAGBO's party, the FPI arguing that France was supporting the rebellion to the detriment of the legitimate government, making difficult the implementation of the Linas- Marcoussis agreement. 
In March 2004, a demonstration was violently repressed, with over one hundred people wounded or killed, the assassination of a Canadian-French journalist, disappearances and other atrocities. Furthermore, the freedom of press came under attack as the Young Patriots, youth militia loyal to President Gbagbo, started attacking opposition newspapers (Amnesty International ,2006).

A direct dialogue between President Gbagbo and the Forces Nouvelles, mediated by former President of Burkina Faso Blaise Compaore, led to the Ouagadougou Peace Agreement in March 2007. The 2007 Ouagadougou Agreement allowed the formation of an interim government of unity that would implement a program of identification of the population and organize open and transparent elections (International Crisis Group, 2007:2-3; US State Department, 2011). This interim government was in charge of implementing a program of identification of the population and organizing open and transparent elections (International Crisis Group, 2007: 2-3; US State Department, 2011).

Having been rescheduled several times presidential elections finally took place in late 2010. In the second round, a coalition between the party of Henri Konan Bédié and that of Alassane Ouattara allowed the latter to win election, leaving behind his main contender Gbagbo. Ouattara had the support of the EU, which recognized his victory in the elections. The Constitutional Council declared Gbagbo the winner Friday, invalidating earlier results from the Independent Electoral Commission, which handed Ouattara the victory with $54.1 \%$ of the vote. It was the job of Y.J. Choi, the special envoy in the Ivory Coast of U.N. Secretary-General Ban Ki-moon, to review and sign off on the results. Choi said that, even if Gbagbo's complaints were taken into consideration, Ouattara was the winner. Yet, Gbagbo refused to accept his defeat.

\section{A Critical Assessment of EU's Responses and Critiques of Norms' Promotion The Zimbabwean case}

After the 2000 elections, the EU made several public declarations condemning the lack of press freedom and the violence against the opposition (Council of the EU, 2000; 2001a). In February 2001, an attempt was made to start political dialogue under Article 8 of the Cotonou Agreement, but this did not get any further than some quarrels about the agenda (Del Biondo, 2012). In June 2001, the EU stated that urgent progress was needed on the end of political violence, international observation to the 2002 presidential elections, press freedom and the independence of the judiciary and (Council of the EU, 2001b). In October 2001, the EU opened consultations under Article 96 of the CPA. During the consultations, the EU asked the government of Zimbabwe to normalize the situation in the country, mainly with respect to the monitoring of the March 2002 elections by international observers, the end on the violations of political and civil rights, of the repression of opposition and the holding of free and fair elections. The consultations ended in a stalemate since there was serious disagreement between the EU and the Zimbabwean delegation on whether foreign journalists and EU observers should be allowed to monitor the 2002 presidential elections (Council of the EU, 2002c). The government of Zimbabwe finally promised that foreign observers 
would be allowed except some EU nationalities mainly British observers. When the Zimbabwean authorities revoked the visa of the head of the EU-EOM Pierre Schori only one week after his arrival, this prompted the EU to adopt "appropriate measures" against Zimbabwe (Laakso et al., 2007: 74). The EU decided to close consultations and to take the appropriate measures, within the meaning of the article $96(2) \mathrm{d}$ of the Cotonou agreement ${ }^{1}$. Moreover, targeted sanctions were taken against those responsible for political violence, including the freezing of their assets and a visa ban. Furthermore, an arms embargo was imposed (Council of the EU, 2002d). A few months later, the Council suspended all bilateral Ministerial contact with Zimbabwe (Council of the EU, 2002e). The period of application of the sanctions was periodically extended after twelve months, namely in February 2003, 2004, 2005, 2006, 2007, 2008, and 2009 considering the unchanging democratic and human rights situation in the country.

The signing of the Global Political Agreement (GPA) opened a new chapter for Zimbabwe: the restrictive measures changed their purpose with the first delisting in early 2010 (see Council Decision 92 of 15 February 2010). The EU further approved positive measures to encourage the implementation of the agreement. From constraining the activity of the government, the EU began to adjust sanctions to consolidate the transitional process, to favor cooperation among the parties, and to encourage the approval of a new constitution. The EU also decided in February 2012 to remove 51 individuals and 20 entities from the visa ban and the asset freeze list in recognition of the implementation of the GPA, which allowed the creation of the Government of National Unity (GNU) and progress made towards the creation of a conducive environment for the holding of free, fair, peaceful and transparent elections.

On 23 July 2012 the EU, further encouraged by the progress made in implementing the GPA by the GNU, suspended the measures applied under Article 96 of the Cotonou Agreement to allow the EU to work directly with the GNU to develop new assistance programs for the benefit of the people of Zimbabwe that would come on stream under the next EDF (See Delegation of the EU to the Republic of Zimbabwe Website). On February 18, 2013, the EU suspended travel bans imposed on 6 members of the Government of Zimbabwe and delisted 21 people and one entity subject to restrictive measures. This was in response to the political parties' agreement on the draft constitution and the announcement of a referendum.

On 25 March 2013 and in view of the outcome of the Zimbabwean constitutional referendum of 16 March $2013^{2}$, the Council has decided to suspend the travel ban and asset freeze applying to the majority of the individuals and entities set out in Annex I to Decision 2011/101/CFSP

1 These measures included the suspension of the budgetary support under Zimbabwe's $7^{\text {th }}$ and $8^{\text {th }}$ EDF National indicative program; the suspension of financial supports for all projects, except those in direct support to the population; re-orientation of financial support to assist the population; suspension of the signature of the $9^{\text {th }}$ EDF NIP; suspension of annex 2 of article 12 of the CPA, and evaluation of regional projects on a case-by case basis.

2 The new constitution, which limits future presidents to five-year terms, was backed by more than three million votes - nearly $95 \%$ of those who voted. The clause limiting presidential terms will not apply retrospectively, so Zanu-PF's 89-year-old leader, President Robert Mugabe, will be able to stand again in elections expected in July (http://www. bbc.co.uk/news/world-africa-21845444) 
(except Mugabe). The removal of the remaining restrictive measures depended on the fairness and openness of the upcoming presidential elections held on 31 July 2013 that should have been certified by the SADC and the African Union within two months after the elections were held. The EU further expressed serious concerns over alleged irregularities in the 2013 presidential elections won by Robert Mugabe. Therefore "the EU underlines the importance and need to continue strengthening reforms to ensure that future elections are fully transparent and credible as well as peaceful" 3 .

Although keeping targeted sanctions against Mugabe and his closest circle, the EU lifts on 23 September 2013 the sanctions against the Zimbabwe Mining Development Corporation ${ }^{4}$. As a reminder, the ZMDC was targeted by an EU- ban of diamonds trading with EU because of the allegation that it was "associated with the ZANU-PF faction of government after the 2008 presidential election. At the same time, since the late 2008, the Marange diamonds (owned by the state-run company ZMDC) was targeted by the Kimberley Process (KP) standards ${ }^{5}$ due to ongoing legal wrangles and government crackdowns on illegal miners and allegations of forced labor and in November 2009 the Marange diamonds were barred from trading. However, in November 2011 an agreement were reached in Kinshasa, which totally lifted the bans on the Marange diamonds, and the European Commission that represents the EU in the Kimberley process has played an active role in the reaching of this agreement ${ }^{6}$. Although backing the reaching of the agreement in Kinshasa, the Marange diamonds remained under the EU-sanctions list until 2013.

A major step towards the normalization of the EU-Zimbabwe relations came out with the lifting of the appropriate measures following the absence of serious deterioration of the governance and human rights situation since the Declaration of 19 February 2014 by the High Representative on behalf of the European Union, following the review of EU- Zimbabwe relations. This expiration of the appropriate measures took effect from November 1, 2014 and will enable the European Union, for the first time since 2002, to make multi-year aid commitments to Zimbabwe and to work with the Government of Zimbabwe under the CPA framework.

3 See Declaration by the High Representative, Catherine Ashton, on behalf of the European Union following the presidential elections in Zimbabwe, Brussels, 22 August 2013 13092/13, PRESSE 357

4 See Council Decision 2013/160/CFSP of 27 March 2013 amending Decision 2011/101/CFSP concerning restrictive measures against Zimbabwe.

5 The Kimberley Process grew out of discussions in May 2000 in Kimberley, South Africa among interested governments, the international diamond industry and civil society, as a unique initiative to combat 'conflict diamonds' - rough diamonds used to finance devastating conflicts in some of Africa's diamond-producing countries. In November 2002, an agreement was reached on the Kimberley Process Certification Scheme (KPCS): an innovative system imposing extensive requirements on all Participants to control all imports and exports of rough diamonds and to put in place rigorous internal controls over production and trade to ensure that conflict diamonds could not enter the legal diamond trade(http://europa.eu/rapid/press-release_IP-10-856_en.htm? locale $=$ en).

6 Answer given by high representative/vice-president Ashton on behalf of the commission on 7 February 2012 to a parliamentary written question; http://www.europarl.europa.eu/sides/getAllAnswers.do? reference=E 
Analyzing the EU's reactions towards the political situation in Zimbabwe since 2000, we can argue that until the year 2008 the EU has followed a normative stance by constantly renewing sanctions due to the perceived lack of improvement of the political and democratic situation in Zimbabwe. In accordance with the NPE theory, the EU's normative characteristics had pushed it to act in a normative way by putting norms and values above any political and economic considerations in its interactions with the Zimbabwean authorities. There has then been a perfect causal relationship between the worsening political situation of Zimbabwe and the establishment and renewal of sanctions. However, from 2008 onwards, the EU's attitude has largely been inconsistent with its claimed normative power status. Indeed, although the signature of the Global Political Agreement has brought about a relative end of political violence in Zimbabwe, it did not improve a lot the democratic landscape of this country. This has been further proven by the fact that the 2013 presidential elections were considered by the EU to be marred with irregularities but this did not impede the EU to resume development cooperation with Zimbabwe in 2014. As such, we can argue that the easing of sanctions against the Mugabe regime constitutes a signal of the perceived ineffectiveness from EU leaders of its sanctions to boost democratic changes in Zimbabwe rather than an indication of democratic improvements.

In the same stance, the NPE seems to be compromised by the controversial attitude of the EU towards ZMDC. Indeed, the position taken by the EU seemed to us controversial: why did the EU back the Kimberley process agreement allowing the exports of diamonds from the Marange mines owned by ZMDC while maintaining the trade embargo against ZMDC? It is generally claimed that unlike the USA, EU is a normative power using normative means, of which the reliance on multilateralism over unilateralism, in the conduct of its external policies. As such for the sake of its long-term commitment to multilateralism, EU was expected to follow the Kimberley Process agreement by lifting the sanctions on ZMDC. But the EU did not act in this way. Does this mean that some of the EU norms weigh much more than others in its foreign policies? Most of EU leaders have backed their support for Zimbabwe in the Kimberley process on humanitarian grounds, arguing that this agreement is a positive outcome not only for the Kimberley Process but also for the people of Zimbabwe, enhancing transparency so that they can benefit from the revenues that will derive from the export of their natural resources. However, and contrary to the hope for more transparency expressed by the EU, many civil society organizations found out that "the Zimbabwean military remaining deeply involved in diamond mining in Marange, persistent and widespread smuggling and no progress in enabling small scale miners to work legally. Regular reports of human rights abuses against miners by security forces continue" (Global Witness, 2011).

The EU decision to lift sanctions on ZMDC in September 2013 allowing for the exports of diamonds to the EU states, further leaves us perplex with many questions in mind: Is it in order to comply with the decisions of multilateral institutions constituted here by the Kimberley process? Is it in the pursuit of pure economic interests? Is it a response to an eventual improvement of the human rights and democratic situation in Zimbabwe? 
One evidence is that Belgium was one of the EU countries that put pressure on the EU to lift the sanctions against ZMDC. Immediately after the de-listing of ZMDC off EU sanctions, the Belgium's Federal Public Service Economy released a statement expressing its satisfaction with the decision by underlying that "Thanks to the support of the Belgian authorities, the decision to lift the restrictive measures will result in diamonds commercialized by the Mines and Minerals Corporation of Zimbabwe to be sold at their optimal market value instead of the current lower prices in other markets" (Mukwakwami, 2013). The Belgium-based Antwerp World Diamond Centre also welcomed this EU removal of sanctions against ZMDC by stating that "this decision will also improve the position of the EU within the [Kimberley Process]. The EU decision to maintain restrictive measures was incompatible with the decision taken at the KP Plenary meeting...to lift all measures on the trade of Marange diamonds" (Bates, 2013).

Critics said that this Belgium's attitude was due to its concerns over protecting its own economic interests, especially to allow the Belgium-based Antwerp World Diamond Centre to continue importing diamonds from Zimbabwe. In fact, "with almost $25 \%$ of rough diamonds now coming from Zimbabwe, Belgium wanted to ensure that Zimbabwe's diamonds passed through Antwerp, a situation not possible if ZMDC remained under sanctions" (Mukwakwami, 2013). In this lens, many NGOs active on the issue strongly disagree with the EU decision, stressing out that "The EU should have given more time to investigating these claims before lifting sanctions. Now it will be left to European consumers and jewelry companies to ensure that Zimbabwe's tainted diamonds are not sold in our shops" (Bates, 2013).

In sum, the EU's role in the Kimberley process on the Marange diamonds show how difficult and hard it could be for the EU to find a right balance between its normative commitments to democracy and human rights and its concern over the effectiveness of multilateral institutions (here the Kimberley Process) and geostrategic economic interests of some EU member states.

\section{The Ivory Coast Case}

After the December 1999 coup d'état, EU for the first time applied restrictive measures prior to the opening of consultations, which measures consisted of refraining from any new financial commitments in Ivory Coast, apart from possible humanitarian projects or projects of direct benefit to the poorest sections of the population (Portela, 2010). Thereafter, the EU opened consultations on 7 February 2000 on the basis of articles 5 and 366a of Lomé $4^{\text {th }}$ convention. On the timetable, the acting Ivorian authorities pledged to restore democracy and agree for the holding of elections, the adoption of the constitution, the separation of powers and a free press and transparency. Consultations were concluded in May 2000. Satisfied with these commitments, the EU decided not to suspend co-operation but to adopt appropriate steps including "the pursuit of co-operation on a gradual and conditional basis, focusing during the transition period on measures in support of the rapid and full restoration of constitutional democracy, the rule of 
law, good governance and civil society, and, should the need arise, humanitarian aid" (Santiso, 2002:124).

The EU judged that the October and December 2000 presidential and legislative elections lacked openness due to restrictions for the opposition candidates and acts of violence. Consequently, EU again called for consultations following the flawed presidential and legislative elections of 2000, pointing to unfulfilled commitments that had been agreed in the previous rounds of consultations under article 366a of the Lomé convention. A second round of consultation was therefore opened on 15 February, this time under article 96 of the Cotonou Agreement. During the consultations, the Ivorian party promised "to conduct a transparent investigation into the atrocities perpetrated during the military regime, and to open the political system” (Portela, 2010).

Encouraged by the inclusive and transparent local elections held in March 2001, the EU decided to conclude the consultations in July 2001 and appropriate measures taken were "a gradual and conditional approach toward new projects in support of the restoration of constitutional democracy, the rule of law, good governance and civil society" (Council of the EU, 2001b).

The relations were normalized in January 2002 after the government of Côte d'Ivoire had made progress in national dialogue, electoral arrangements and press freedom although GBAGBO still needed to deliver on some of the promises made, including the investigation of violence (Council of the EU, 2002a). The EU condemned the attacks against a legitimate government (Council of the EU, 2002b). The EU also supported the signature 2003 Linas-Marcoussis Agreement led by France, which resulted in the formation of a government of national reconciliation involving all political parties and the rebellion group, the MPCI. Following a violent repression of the march of the opposition in March 2004, the European Commission proposed the opening of consultations (Council of the EU 2004). Yet, the council (France and Germany particularly) rejected the proposal, arguing that the threat of civil war would render article 96 consultations ineffective (Laakso et al.2007: 85).

Following the 2007 Ouagadougou Agreement, a new country strategy paper and National Indicative Program was signed in 2007, and the EU agreed to support the implementation of the agreement with a view of the 2010 presidential elections. The EU financed the identification process and provided electoral assistance (see website of the EU Delegation in Cote d'Ivoire). An EU Election Observation Mission was sent to monitor the 2010 elections. After the turmoil of the 2010 presidential elections, the United Nations General Assembly, European Union, U.S. government and neighboring African leaders all defended the electoral commission's findings and officially recognized Alassane Ouattara and his ministers and ambassadors as official representatives of Ivory Coast. In accordance with UN Security Council Resolution 1975, the EU has also passed "selective sanctions" on Laurent Gbagbo's circle of supporters, implementing travel bans and freezing assets in overseas bank accounts. Targeted sanctions were gradually imposed on President Laurent Gbagbo and 124 of his staff, as well as on 13 economic entities that 
remained in the hands of Laurent Gbagbo, such as the Port of Abidjan and San Pedro ${ }^{7}$. Faced with the persisting refusal of Laurent Gbagbo to accept his defeat following the contested presidential elections of 2010-2011, France again took on a more active role in April 2011 and together with the UN Operation in Cote d'Ivoire (UNOCI) troops it launched an offensive on the presidential palace with the aim of helping forces loyal to Alassane Ouattara to topple Laurent Gbagbo. This 2011 intervention officially conducted under UNSC resolution 1975 of 30 March 2010 allowed Alassane Ouattara's forces to enter the palace and arrest Laurent Gbagbo, his wife and some of his supporters. On grounds however, it is argued that French soldiers directly participated in the arrest of Laurent Gbagbo helped Alassane Ouattara forces to enter into the presidential palace.

The EU has also taken post-crisis measures in order to support stabilization and the economic recovery of the country. It has therefore lifted assets freeze on the ports of Abidjan and S. Pedro, SRI, and the cocoa/coffee management committee; the five national banks and PETROCI on 8 April 2011. Moreover, through its Foreign Affairs Council conclusions of 12 April 2011, the EU commits to cooperate fully with the elected government and support the restoration of law and order as well as social and political reconciliation. In addition to swiftly resuming EDF cooperation projects, the EU prepares an early recovery package to bridge the early recovery gap; and humanitarian assistance continues. The remaining sanctions will be progressively lifted in close consultation with the government to support the country's economic recovery and national reconciliation process (Council of the EU, 2011).

Regarding the EU's attitude towards the evolution of the situation in Ivory Coast, one could argue that overall the EU has not been consistent with its normative power feature. To begin with, the EU did not suspend its cooperation with Ivory Coast following the 1999 coup d'etat but instead decided to take a conditional approach to development cooperation on the simple basis of a pledge by the Ivorian leaders to restore democracy. This is in contradiction with the EU's general reflex of suspending ipso fact cooperation with a third country whenever a coup d'état intervene because this is a clear demonstration of the breaking of the democratic rules in a country. In the same manner, the EU did not systematically suspend cooperation with Ivory Coast following the 2000 contested presidential election, it once again took a conditional basis approach after the relatively peaceful local elections were held in 2001.The EU even went further by normalizing its relations with Ivory Coast in 2002 after improvements made by the Ivorian authorities in national dialogue, electoral arrangements and press freedom although no progress was made on the issue of violence investigation. The European Commission's proposal to open consultations under article 96 of the CPA following the 2004 violence was mainly rejected by France in the Council. The underlying reasons behind France attitude might be that France needed to maintain good relationships with the then Ivorian authorities to protect its commercial interests in this country.

$7 \quad$ See Council Decision 2011/221/CFSP amending Decision 2010/656/CFSP renewing the restrictive measures against Côte d'Ivoire; Council Regulation (EU) No 330/2011 amending Regulation (EC) No 560/2005 imposing certain specific restrictive measures directed against certain persons and entities in view of the situation in Côte d'Ivoire; Council Decision 2011/71/CFSP of 31 January 2011 amending Decision 2010/656/CFSP renewing the restrictive measures against Côte d'Ivoire. 
In addition, the EU's attitude during the 2010-2011 contested presidential elections in Ivory Coast was not less controversial. Whereas the EU was somewhat reluctant to adopt sanctions against Laurent Gbagbo between 2000-2005, its position has suddenly become harder from 2005 to 2010 against Laurent Gbagbgo, despite the fact that the human rights and democratic situations in-between these two periods are quasi-similar. By officially taking side with the camp of the current president, Alassane Ouattara trough official recognition and by putting sanctions against Laurent Gbagbo and its family, the EU's action has greatly undermined its legitimacy and credibility from the majority of the population supporting the incumbent president Laurent Gbagbo. As such, the country is experiencing now a serious problem of national reconciliation, profound ethnical division and harassment against ex-political leaders of the FPI by the current government. This is exacerbated by the fact that the military forces of one EU member state, namely France, are accused of having played a leading role in the capture of Laurent Gbagbo and its surrounding to the International Criminal Court. As such, the normativity of the EU as a whole can hardly be effective unless individual member states' foreign policies are consistent with the desire of the EU to conduct normative foreign policy. In the specific case of Ivory Coast, the unilateral foreign policy pursued by France to protect its commercial interests in this country has significantly undermined the normative power of the EU because it has limited its capability to act in a normative way via the use of veto power in the council.

\section{Conclusion}

This article has critically analyzed the limits of the EU's normative power in the context of the political situation in Zimbabwe and Ivory Coast between 2000-2014. The EU's external policies with the ACP group of states has evolved from a purely economic relationship to an increasing political partnership since the amended $4^{\text {th }}$ Lome Convention reinforced later by the Cotonou Agreement. Basically, the introduction of political conditionality into these framework means that ACP group of countries have to deserve the EU's development aid by fulfilling political conditions. The analysis has shown that the EU's reactions against the political situation in Zimbabwe from 2002 to 2008 have been somewhat consistent with its normative power feature. In fact, the EU has constantly reacted harshly towards the worsening of the democratic situation in Zimbabwe between 2000-2008 by renewing sanctions on the basis of the annual review by the European Commission. However, from 2008 onwards, the EU's ease of sanctions against the Mugabe regime despite the non-improvement of the democratic situation in this country, clearly demonstrate that norms are not always at the cornerstone of EU's foreign policy towards third countries. In this particular case of Zimbabwe, the gradual lifting of sanctions reflected more an admission by the $\mathrm{EU}$ of the ineffectiveness of its sanctions to induce democratic changes in this country than a reward for perceived democratic advancements. In the same vein, the EU's contradictory policy of lifting economic sanctions against ZMDC, despite the fact that the Marange diamonds are still used by the Zimbabwean government as an asset to continue with human rights abuses have shown that there is a gap between rhetoric and practice, as the EU sometimes trade off norms with material considerations. Likewise, the EU's reluctance to adopt harsh measures 
against the Ivorian authorities following the 1999 coup d'état and the 2000 controversial elections makes it clear that the EU does not always act in a normative way as NPE theory argues. It has become even more clearer that economic interests trump EU's normative considerations when the Commission's proposal to open consultations with the Ivorian authorities following the 2004 violent march repression was blocked by France in the Council and when the EU did not hesitate to adopt hardcore sanctions against Laurent Gbagbo following the 2010-2011 elections while it was reluctant to adopt the same sanctions in face of quasi-similar democratic and human rights violations committed in the country.

A lack of consistency in addressing concerns about human rights and democratic principles is very likely to damage the EU's credibility, self-image and to challenge the definition of the EU as a normative power. Thus, aid conditionality needs to be implemented with integrity by the EU at any time and at any place, involving the fair and equal treatment of all nations. 


\section{References}

Blair, A. (2004). Diplomacy: The Impact of the EU on its Member States. In W. Carlsnaes, H. Sjursen and B. White eds., Contemporary European Foreign Policy, $1^{\text {st }}$ ed. London: Sage, pp.198-210.

Amnesty International (2002). Zimbabwe: Hundreds Detained in Politically Motivated Crackdown. 12 March 2002, London: Amnesty International.

Amnesty International (2004). Zimbabwe: Human Rights Groups Must Not Be Banned, 23 July 2004, London: Amnesty International.

Amnesty International (2006).Côte d'Ivoire: Journalists Threatened With Death and Rape in Full View of the Ivorian Security Forces", 19 January 2006, London: Amnesty International.

Arts, K. (2000). Integrating Human Rights into Development Cooperation. The Case of the Lomé Convention. The Hague: Kluwer Law International.

Bates, R. (2013). EU Lifts Sanctions on Zimbabwe Diamonds, September 24, 2013.

Accessed at http://www.jckonline.com/2013/09/24/eu-lifts-sanctions-on-zimbabwe-diamonds

BBC News (2013). Zimbabwe Poll Was 'Free, Honest and Credible' - African Union. BBC News. 2 August 2013.

Ble Kesse, A. (2005). Côte d'Ivoire En Guerre,Le Sens De L'imposture Française. L' Harmattan

Bouquet, C. (2011). Cote d'Ivoire: Le Désespoir De Kourouma. Armand Colin.

Cebeci, M. (2012). European Foreign Policy Research Reconsidered: Constructing an 'Ideal Power Europe' through Theory?. Millennium: Journal of International Studies 40(3), pp.563-583.

Council of the EU (2000). Declaration by the Presidency on Behalf of the European Union on Zimbabwe, Brussels, 19 September 2000.

Council of the EU (2001a). Draft Council Conclusions on Zimbabwe, Brussels, 19 June 2001.

Council of the EU (2001b). Council Decision of 25 June 2001 Concluding Consultations with Côte d'Ivoire Under Article 96 of The ACP-EC Partnership Agreement, Council Decision 2001/510/EC, OJ L183, 6 July 2001: 83-41.

Council of the EU (2002a).Cote d'Ivoire - Final Stage of the Resumption of Cooperation, Brussels, 11 February 2002 .

Council of the EU (2002b). Declaration by the Presidency On Behalf Of the European Union on the Events in Côte d 'Ivoire, Brussels, 25 September 2002.

Council of the EU (2002c). Zimbabwe - Consultations Pursuant to Article 96 of the Cotonou Agreement, Information Note, Brussels, 15 January 2002.

Council of the EU (2002d).Council Common Position Concerning Restrictive Measures against Zimbabwe. Council Common Position 2002/145/CFSP, OJ L50, 21 February 2002.

Council of the EU (2002e). Zimbabwe - Draft Council Conclusions. Brussels, 11 April 2002.

Council of the EU (2004). Declaration by the Presidency on Behalf of the European Union on the Situation in Côte d'Ivoire. Brussels, 7 April 2004.

Council of the EU (2011). Factsheet: Cote d'Ivoire: EU Response to Date. 04/05/2011.

Crawford, G (1996). Whither Lomé? The Mid-Term Review and Decline of Partnership. The Journal of Modern African Studies 34 (3), pp. 503-518.

Del Biondo, K. (2011). EU Aid Conditionality in ACP Countries: Explaining Inconsistency in EU Sanctions Practice, Journal of Contemporary European Research.Volume7, Issue3, Pp.380-395, Accessed at Http://Www.Jcer.Net/Ojs/Index.Php/Jcer/Article/View/294/290 
Diez, T. (2005). Constructing the Self and Changing Others: Reconsidering 'Normative Power Europe". Millennium: Journal of International Studies, 33 (3), pp. 613-36.

European Commission (2008). Restrictive Measures. Spring 2008.

Freedom House (2012). Overview Zimbabwe. Accessed at http://www.freedomhouse.org/report/freedomworld/2012/zimbabwe

Global Witness. 2011. Kimberley Process lets Zimbabwe off the hook (again), 2nd November 2011.

Available at http://www.globalwitness.org/library/kimberley-process-lets-zimbabwe-hook-aga

Grebe, J. (2010). And they are still targeting: Assessing the effectiveness of targeted sanctions against Zimbabwe. Africa Spectrum 1/2010,pp. 3-29.

Hardwick, D. (2011). Is the EU a Normative Power?. E-International Relations Students. Available at, http:// www.e-ir.info/2011/09/03/is-the-eu-a-normative-power/ [Accessed 4 Apr. 2016].

Hill, C \& Smith, M. (2011). International Relations and the European Union. Oxford: Oxford University Press.

Hyde-Price, A. (2006). Normative Power Europe: A Realist Critique. Journal of European Public Policy 13(2), pp. 217-234.

Hyde-Price, A. (2008). A 'Tragic Actor'? A Realist Perspective On 'Ethical Power Europe. International Affairs, Vol.84, No. 1 (January), pp.29-44.

International Crisis Group (2002). Zimbabwe's Election: the Stakes for Southern Africa, Africa Briefing, 11 January 2002, Harare/Brussels: International Crisis Group.

International Crisis Group (2003).Côte d'Ivoire: 'The War Is Not Yet Over', Africa Report N²72, 28 November 2003, Freetown/Brussels: International Crisis Group.

International Crisis Group (2007). Côte d'Ivoire: Faut-Il Croire A L'accord De Ouagadougou? Africa Report $\mathrm{N}^{\circ} 127,27$ June 2007, Dakar/Brussels: International Crisis Group.

Laakso, L., Kivimäki, T. and Seppänen, M. (2007). Evaluation of Coordination and Coherence in the Application of Article 96 of the Cotonou Partnership Agreement. Appendix with Case Studies, Triple C Evaluations $N^{\circ} 4$. Amsterdam: Aksant.

LegalBrief Today (2013). Group urges Zimbabwe election audit, Issue No: 3338, 15 August 2013.

Manners, I. (2002). Normative Power Europe: A Contradiction in Terms. Journal of Common Market Studies 40/2,pp. 235-258.

Metreveli, T. (2011). The EU's Normative Power - Strength or Weakness?.[online]Atlantic-Community, (April), pp.1-16.

Available at,

http://www.atlanticcommunity.org/app/webroot/files/articlepdf/EUNormativePower.pdf/[Accessed Feb. 2017]

Mukwakwami, N. (2013). A critique of the de-listing of ZMDC off the European Union Sanctions list. Project263, October 21,2013,

https://projekt263.wordpress.com/2013/10/21/a-critique-of-the-de-listing-of-zmdc-off-the-europeanunion-sanctions-list/[Accessed 25 Feb. 2017]

Nye, J.S. (2005). Soft Power -The Means to Success in World Politics. New York: Public Affairs.

Olsen, G. (2002). The European Union: An Ad Hoc Policy with a Low Priority. In P. J. Schraeder (Ed.), Exporting Democracy: Rhetoric Vs Reality (pp. 131-146). Boulder, Colorado, USA: Lynne Rienner Publishers. 
Ozveri, D. (2011). Promoting Human Rights by Conditionality? Quest for A Better EU Development Assistance in ACP Countries. In Third Global Studies Conference, 17-20 August 2011, University Of Porto, Portugal (Panel: FB07).

Portela, C. (2010). European Union Sanctions and Foreign Policy: When and Why Do They Work? Routledge: London and New York.

Prodi, R. (2000). 2000-2005: Shaping the New Europe. Speech to the European Parliament, 15th February 2000.

Accessed from:http://europa.eu/rapid/pressReleasesAction.do?reference=SPEECH/00/41\&format=HTML\&a ged $=1$ \&language $=$ EN\&guiLanguage $=$ en

Reporters without Borders (2013). Opposition also Threatens Media. Published On Tuesday 11 June 2013.

Santiso, C. (2002). Promoting Democracy by Conditioning Aid? Towards A More Effective EU Development Assistance. The American Consortium on EU Studies (ACES) Working Paper (2002.4) Washington.

Sjursen, H. (2006). The EU as a 'normative power': how can this be?. Journal of European Public Policy, 13:2, pp.235-251.

US State Department (2011). Background Note: Côte D“Ivoire. Available at https://www.state.gov/r/pa/ei/ bgn/2846.htm, October 2011. 